Research Article

\title{
Three Years Retrospective Study of Melanocytic Lesion in Tertiary Hospital: Comparing Benign \& Malignant Data
}

\author{
Fitri A. Ramadhini, ${ }^{1}$ Theresia R. Yunita, ${ }^{1}$ Larisa P. Wibawa, ${ }^{1 *}$ Melody F. Andardewi, ${ }^{1}$ \\ Inge A. Krisanti, ${ }^{1}$ Adhimukti T. Sampurna, ${ }^{1}$ Riesye Arisanty ${ }^{2}$ \\ ${ }^{1}$ Department of Dermatology and Venereology \\ ${ }^{2}$ Department of Anatomical Pathology \\ Faculty of Medicine, Universitas Indonesia - dr. Cipto Mangunkusumo Hospital, Jakarta \\ *Corresponding author: larisa.paramitha@ui.ac.id \\ Received 20 March 2020; Accepted 19 March 2021 \\ DOI: 10.23886/ejki.9.10.
}

\begin{abstract}
Melanocytic lesion is defined as skin symptom due to proliferation of melanocytes. It may be considered benign, commonly diagnosed as melanocytic nevus $(M N)$, or may also be malignant as malignant melanoma (MM). Publication of epidemiologic data about melanocytic lesion in Indonesia is limited. The aim of this study was to evaluate the epidemiologic findings of melanocytic lesion based on histopathology and clinical data. This descriptive study was done by collecting retrospective pigmented lesion from histopathology database at Department of Anatomical Pathology dr. Cipto Mangunkusumo National Hospital from 2014 - 2017. Retrieved data were analyzed descriptively for $M N$ and MM include clinical diagnosis, age, sex, location, size and clinical working diagnosis. There were 121 cases of melanocytic lesions consisting of $87.6 \% \mathrm{MN}$. Females were more frequent for benign lesions. MN cases were mostly seen at the age below the fourth decade, while from 12 cases of MM found above fourth decade. MN was located mostly on the head and neck, while MM mostly in the lower extremities and soles. There were 75 lesions size and 4 lesions location were unknown data missing. $\mathrm{MM}$ is still considered rare. Completing clinical finding in the histopathology request form by surgeons will aid in defining better characteristic of melanocytic lesion in our population.

Keyword: epidemiology, melanocytic lesion, nevus melanocytic, malignant melanoma.
\end{abstract}

\section{Studi Retrospektif Lesi Melanositik dalam Tiga Tahun di RS Tersier: Perbandingan Data Jinak dan Ganas}

\begin{abstract}
Abstrak
Lesi melanositik didefinisikan sebagai lesi kulit akibat proliferasi melanosit. Lesi melanositik dapat dianggap jinak, umumnya didiagnosis sebagai nevus melanositik (NM), atau merupakan ganas yaitu melanoma maligna (MM). Publikasi data epidemiologi tentang lesi melanositik di Indonesia masih terbatas. Tujuan dari penelitian ini adalah untuk melakukan evaluasi gambaran epidemiologis lesi melanositik berdasarkan data histopatologi dan klinis. Penelitian deskriptif ini dilakukan dengan mengumpulkan data retrospektif lesi berpigmen dari basis data histopatologi di Departemen Patologi Anatomi Rumah Sakit Nasional dr. Cipto Mangunkusumo dari tahun 2014 - 2017. Data dianalisis secara deskriptif untuk NM dan MM termasuk diagnosis kerja, usia, jenis kelamin, lokasi, ukuran, dan diagnosis klinis. Terdapat 121 kasus lesi melanositik yang terdiri atas 87,6\% NM. Lesi jinak lebih banyak ditemukan pada wanita. Terdapat 75 dan 4 kasus dengan data ukuran lesi dan lokasi tidak tercantum. MM masih dianggap jarang. Kasus NM sebagian besar terlihat pada usia di bawah dekade keempat, sedangkan dari 12 kasus MM di atas dekade keempat. NM sebagian besar terletak di kepala dan leher, sedangkan MM ditemukan di ekstremitas bawah dan telapak kaki. Melengkapi temuan klinis dalam formulir permintaan histopatologi oleh dokter bedah akan membantu dalam menentukan karakteristik lesi melanositik lebih baik pada populasi ini.
\end{abstract}

Kata kunci: epidemiologi, lesi melanositik, nevus melanositik, melanoma maligna. 


\section{Introduction}

Melanocytic lesion is defined as skin symptom due to proliferation of melanocytes. Melanocytes are pigment-producing cells whose main function is to protect the skin from ultraviolet damage. Proliferation of melanocytes maybe considered benign, commonly diagnosed as melanocytic nevus (MN), or may also be malignant known as malignant melanoma (MM). ${ }^{1}$ Many MN may appear similar to $\mathrm{MM} ;{ }^{2}$ several variant of $\mathrm{MN}$ may progress to $\mathrm{MM}{ }^{3}$ also increasing number and size of $\mathrm{MN}$ for certain individual may also increase their risk to develop into MM. ${ }^{4}$ This fact poses MN not just as differential diagnosis but also as a precursor for MM.

MM incidence continues to rise and is one of the most aggressive and lethal form of skin cancer, most of them derived from white population. ${ }^{5}$ In the United State, the rate of new cases of MM was 22.7 per 100,000 men and women per year, with the death rate 2.4 per 100,000 men and women per year. When detected early, MM have $99 \%$ five yearsurvival rate. ${ }^{6}$ The need to detect $\mathrm{MM}$ at an early stage is crucial to reduce its morbidity and mortality.

MM is rare in people of color (POC), but most of them came in the later stage, which reduced their survival rate. $\mathrm{POC}$ have different clinical presentation of MM compared to the white population. In POC, MM is located in acral region, which suggests that sun exposure is not the causal risk factor. They have a significantly lower density of $\mathrm{MN}$, which indicate a lack of correlation between nevi density and $\mathrm{MM}$ in POC. ${ }^{7}$ At present, the epidemiologic data about melanocytic lesion in Indonesian population is limited. Previous available studies are histopathologic study of malignant melanoma ${ }^{8}$ and nevus pigmentosus ${ }^{9}$ at Central General Hospital Dr. Mohammad Hoesin Palembang (2009-2013), and only one study comparing benign and malignant melanocytic lesion based on histopathology in Yogyakarta (1986-1989). ${ }^{10}$

This study aims to evaluate the clinical characteristics of melanocytic lesion based on histopathology data and medical record at Cipto Mangunkusumo National Hospital (CMNH).

\section{Methods}

This descriptive study was done by collecting retrospective data from histopathology database at Department of Anatomical Pathology CMNH from June 2014-June 2017. A lesion was considered melanocytic lesion if there was proliferation of melanocytes. Data for melanocytic lesion were collected with total sampling and classified into $\mathrm{MN}$ and MM. The characteristics of MN and MM included are age, sex, location, size, and clinical working diagnosis. Missing data were then added from the medical records if available. Retrieved data were analyzed descriptively using Microsoft Excel ${ }^{\circledR}$ for Mac 2011 version 14.3.0. This study has been approved by the Ethic Committee of Faculty of Medicine, Universitas Indonesia (0151/UN2.F1/ ETIK/2018).

\section{Results}

Figure 1 shows 121 cases of melanocytic lesions consisting of 15 lesions (12.3\%) MM and 106 lesions (87.7\%) MN based on histopathology. Most patients in MM were above 40 years old (12 lesions) and in $\mathrm{MN}$ the incidence was higher below 40 years old (73 lesions).

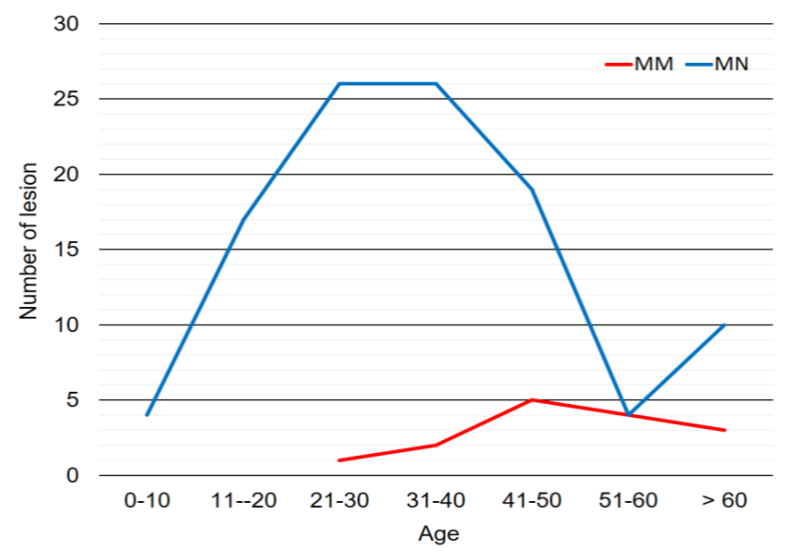

Figure 1. Distribution of Malignant Melanoma (MM) and Melanocytic Nevus (MN) According to Age Groups in Years ( $n=121$ lesion)

Most of melanocytic lesions predominantly in female population (86 lesions) (Table 1). In MM most of frequent site was on lower extremities and soles (10 lesions). From four lesions of MM on the head and neck, two of them were periorbital region (ocular melanoma). For $\mathrm{MN}$, the incidence was higher in head and neck (83 lesions). Sixty-two percent missing data about lesion diameter were found in this study. In MN most of lesion diameter were greater than $5 \mathrm{~mm}$ (35 lesions).

Most of the MN patients were female (79 lesions) and were located in the head and neck region (61 lesions) (Table 2). 
Table 1. Frequency of Malignant Melanoma and Melanocytic Nevus Based on Gender, Sites, and Size of Lesions

\begin{tabular}{|c|c|c|c|c|c|c|}
\hline \multirow{2}{*}{ Variable } & \multicolumn{2}{|c|}{ Malignant Melanoma } & \multicolumn{2}{|c|}{ Melanocytic Nevus } & \multirow{2}{*}{ Total } & \multirow{2}{*}{$\%$} \\
\hline & $n=15$ & $\%$ & $n=106$ & $\%$ & & \\
\hline \multicolumn{7}{|l|}{ Gender } \\
\hline Female & 7 & 46.67 & 79 & 74.52 & 86 & 71.07 \\
\hline Male & 8 & 53.33 & 27 & 25.48 & 35 & 28.93 \\
\hline \multicolumn{7}{|l|}{ Sites } \\
\hline Head \& neck & 4 & 26.67 & 83 & 78.30 & 87 & 71.90 \\
\hline Trunk & 0 & - & 13 & 12.26 & 13 & 10.74 \\
\hline Upper extremities & 0 & - & 3 & 2.83 & 3 & 2.48 \\
\hline Lower extremities & 6 & 40.00 & 2 & 1.89 & 8 & 6.61 \\
\hline Palms \& soles & 4 & 26.67 & 0 & - & 4 & 3.31 \\
\hline Buttock \& genitalia & 0 & - & 2 & 1.89 & 2 & 1.65 \\
\hline Not available & 1 & 6.66 & 3 & 2.83 & 4 & 3.31 \\
\hline \multicolumn{7}{|l|}{ Lesion Diameter } \\
\hline Not available & 11 & 73.33 & 64 & 60.38 & 75 & 62.00 \\
\hline$<5 \mathrm{~mm}$ & 0 & - & 7 & 6.60 & 7 & 5.77 \\
\hline$\geq 5 \mathrm{~mm}$ & 4 & 26.67 & 35 & 33.02 & 39 & 32.23 \\
\hline
\end{tabular}

Table 2. Sites of Melanocytic Nevus Based on Gender ( $n=106$ lesion)

\begin{tabular}{lcc}
\hline Sites & Female & Male \\
\hline Head \& neck & 61 & 22 \\
Non-head \& neck & 15 & 5 \\
Not available & 3 & 0 \\
\hline Total & 79 & 27 \\
\hline
\end{tabular}

Summary of various clinical working diagnosis for $\mathrm{MM}$ and $\mathrm{MN}$ were described in Table 3. Many surgeons wrote tumor or mass on certain region as the clinical diagnosis.

Table 3. Various Clinical Working Diagnosis Sent According for Malignant Melanoma and Melanocytic

\begin{tabular}{ll}
\hline Melanocytic lesion & Various Clinical Working Diagnosis \\
\hline Malignant Melanoma & Melanoma malignant \\
& Epithelioid sarcoma \\
& Hyperpigmented nodule \\
& Mass \\
& Tumor \\
Melanocytic Nevus & Melanocytic nevus \\
& Pigmented nevus \\
& Miescher nevus \\
& Split nevus \\
& Nevus spilus \\
& Giant congenital nevus \\
& Amelanotic nevus \\
& Atypical nevus \\
& Hairy nevus \\
& Becker nevus \\
& Epidermal nevus \\
& Sebaceous nevus \\
& Seborrheic keratosis \\
& Epidermal cyst \\
Cylindroma \\
Papilloma \\
Vascular malformation \\
Nevus \\
Mass \\
Tumor \\
\hline
\end{tabular}




\section{Discussion}

The development of melanocytic lesion is a multifactorial and heterogeneous biologic process. Like MM, genetic also plays role in the development of MN. Some external factors including ultraviolet exposure, trauma, and intrinsic factors such as hormonal and age may cause variation of the lesion development. ${ }^{11,12}$ These factors may contribute to the different epidemiologic manifestation of melanocytic lesion in a different population.

Data in this study were collected from histopathology database, which consists of patients from Dermatology and Venereology Department, other Departments in $\mathrm{CMNH}$, and referral from other hospital. The data therefore did not represent all of patients with melanocytic lesion who visited to the outpatient clinic of $\mathrm{CMNH}$, which is a tertiary national hospital in Indonesia. This study found MN comprise of $87.7 \%$ (106 lesions) of all melanocytic lesion and only 15 lesions of MM in three years. The low incident of MM was accord in the similar study in 1994 from Yogyakarta. They found $78.8 \%$ (149 lesions) of pigmented nevus and 40 lesions of MM within 4 years. ${ }^{9}$ This finding in accordance with the study in Palembang, which found 30 lesions of MM in 4 years (2009-2013). ${ }^{8}$ In the same period also in Palembang, a study on pigmented nevus also revealed 151 lesions of $\mathrm{MN}$, with the exclusion of 7 cases of flameus and sebaceous nevus. ${ }^{9}$

Figure 1 showed that most patients in $\mathrm{MN}$ were within age group below 40 years old. Meanwhile, in MM most patient were above 40 years old (12/15 lesions). The data from previous study in Yogyakarta ${ }^{10}$ and Palembang also showed the same characteristic. . $^{8,9}$ This finding is quite similar with the incidence of MM in white population, increased at the fourth decade and peaks at the sixth decade of life. ${ }^{6}$ While for $\mathrm{MN}$ in white population, the incidence significantly increased before and decreased after the fourth decade of life..$^{13}$ This finding support the fact that new pigmented lesion appearing above fourth decade most likely are not MN, and needs further observation to ruled out MM.

MN was higher in females $(74.52 \%)$ in this study. This finding also similar to the data from Yogyakarta and Palembang., ${ }^{9,10}$ Similar finding also acquired in the white population research which performed in clinical or hospital setting. ${ }^{13} \mathrm{We}$ speculate the higher prevalence in female in these study was because female seek treatment for aesthetic purpose compared to male counterpart. This is in line with the data in this study that MN in the female patient were located in the head and neck area, which is considered an aesthetic region. Many epidemiologic studies confirmed that MN are more frequent in the white population compared to other ethnic groups. ${ }^{14}$ In those studies, the males had more nevus counts than females. ${ }^{14,15}$

MM male patient was relatively more prevalent in this study (8/15 lesions). This finding was contradictory from the previous study in the same hospital, ${ }^{16}$ Yogyakarta, ${ }^{10}$ and Palembang. ${ }^{8}$ Those study which found more female patients, had more MM patients compare to the present study might explain the different finding. ${ }^{8,10,16}$ The study from Yogyakarta speculate $\mathrm{MM}$ in female were more prevalent, because they found more $\mathrm{MN}$ in female..$^{10}$ In the United State and Australia, which showed high incidence of MM, it was more prevalent in males. ${ }^{6,17}$ In Queensland, Australia, MM in male was equal to 55.8/105/annum and 41.1/105/annum for females. ${ }^{17}$

Most cases of MM performed biopsy in this study, were found in lower extremities and soles (10/15 lesions). Our finding was in accordance with acral lentiginous melanoma (ALM) which is more common in Asian population. ${ }^{7}$ A study from Japan in the aim to try find the relationship between ALM and MN, conclude that ALM is not correlated to high number of $\mathrm{MN}$ and having $\mathrm{MN}$ in the acral region. ${ }^{18}$ Study from Korea found high prevalence of ALM suggest that this type of MM might be correlated to mechanical stress, which different from the causative of MM in the white population. ${ }^{19}$ Our data also showed MM in head and neck consist of 4 cases among two of them are located in the periorbital region, categorized as ocular melanoma. Previous report from Yogyakarta found $55 \%$ of $\mathrm{MM}$ in the head and neck region. ${ }^{10}$ Incidence rate of ocular melanoma is quite rare even in Asian population. ${ }^{20}$

In this study MN was found higher incidence in head and neck (78\%), similar finding with the histopathologic study in Yogyakarta ${ }^{10}$ and Palembang. ${ }^{9}$ Dermoscopy diagnosis MN study in this same hospital (without histopathologic examination), also found that the most common sites for $\mathrm{MN}$ were on head and neck (43\%). ${ }^{21}$ This is contradictory compared to the study in Spanish children population MN were more prevalent in the trunk area compared to head and neck. ${ }^{22}$ Other study from Japan found more $M N$ in the head and neck compared to other body site. ${ }^{18}$ Anatomic distribution of MN might be different between races, a bigger scale epidemiologic study is needed to determine the distribution characteristic in our population. 
Having a single melanocytic lesion larger than 5 $\mathrm{mm}$ increased the risk of having $\mathrm{MM}^{.}{ }^{23}$ So we seek to find whether size may predict the diagnosis of MM in our population. Unfortunately, in this study $62 \%$ data were missing for lesion diameter. Among the melanocytic lesions under study, 35 lesions were greater than $5 \mathrm{~mm}$ in diameter. All available data found for MM (4/15) the size was more than 5 $\mathrm{mm}$. And thus, we cannot make statistical analysis for this parameter. People who had increased number of large nevi also increased their risk to $\mathrm{MM},{ }^{23}$ so the size of a lesion is a compulsory data to be registered in deciding the diagnosis. Various clinical working diagnosis sent by the surgeon to aid the pathologist in deciding the final diagnosis. Many working diagnoses left blank or still shown as a morphologic description such as tumor, mass, and hyperpigmented nodule. Sufficient clinical data is needed to make a histopathologic correlation. A complete written histopathologic form will determine more correct and fast histopathologic diagnosis. ${ }^{24}$

\section{Conclusion}

Malignant melanoma is still considered rare and mostly located on lower extremities and soles, also mostly seen above the fourth decade. Melanocytic nevi were mostly located in head and neck, with high incidence below the fourth decade. There were many missing data from histopathology request form, especially in size and location. Completing histopathology request form by surgeons is needed to establish national data especially of malignant lesion in Indonesia.

\section{Acknowledgements}

This research was presented as an e-poster in Indonesian Conference of Laser, Aesthetic, and Dermatosurgery, in Bali on April 26-27, 2019.

\section{References}

1. Shain $A H$, Bastian BC. From melanocytes to melanomas. Nat Rev Cancer. 2016;16:345-58.

2. Baade PD, Youl PH, Janda M, Whiteman DC, Del Mar $\mathrm{CB}$, Aitken JF. Factors associated with the number of lesions excised for each skin cancer. Arch Dermatol. 2008;144:1468-76.

3. Haenssle HA, Mograby N, Ngassa A, Buhl T, Emmert $S$, Schön MP, et al. Association of patient risk factors and frequency of nevus-associated cutaneous melanomas. JAMA Dermatol. 2016;152:291.

4. Zaal LH, Mooi WJ, Klip H, van der Horst CMAM. Risk of malignant transformation of congenital melanocytic nevi: a retrospective nationwide study from the Netherlands. Plast Reconstr Surg. 2005;116:1902-9.
5. Matthews NH, Li WQ, Qureshi AA, Weinstock MA, Cho E. Epidemiology of melanoma. In: Ward WH, Farma JM, editors. Cutaneous melanoma: etiology and therapy. Brisbane: Codon Publications; 2017. p.3-22

6. SEER Cancer Stat Facts: Melanoma of the skin. National Cancer Institute. Bethesda, MD, Available from https://seer.cancer.gov/statfacts/html/melan. html. Cited in May $2^{\text {nd }} 2020$.

7. Agbai ON, Kundu RV, Buster K, Chiu M, Sanchez M, Roberts WE, etal. Skin cancer and photoprotection in people of color: a review and recommendations for physicians and the public. J Am Acad Dermatol. 2014;70:748-62.

8. Syaputri NA, Musa Z, Septadina IS. Karakteristik histopatologi melanoma maligna di Bagian Patologi Anatomi RSUP Dr. Moh. Hoesin Palembang tahun 2009-2013. Biomedical Journal of Indonesia: Jurnal Biomedik Fakultas Kedokteran Universitas Sriwijaya. 2018;4:26-31. Indonesian.

9. Tsaniyah RAD, Aspitriani, Fatmawati. Prevalensi dan gambaran histopatologi nevus pigmentosus di Bagian Patologi Anatomi RSUP Dr. Mohammad Hoesin Palembang periode 1 Januari 2009-31 Desember 2013. MKS. 2015;47:110-4. Indonesian.

10. Wiraguna AAGP, Soeripto. Kejadian nevus pigmentosus dan melanoma maligna di Laboratorium Patologi Anatomik Fakultas Kedokteran Universitas Gadjah Mada. Berkala IImu Kedokteran. 1994;26:37-44. Indonesian.

11. Roh MR, Eliades P, Gupta S, Tsao H. Genetics of melanocytic nevi. Pigment Cell Melanoma Res. 2015;28:661-72.

12. Bataille V. Genetic epidemiology of melanoma. Eur J Cancer. 2003;39:1341-7.

13. Zalaudek I, Schmid K, Marghoob AA, Scope A, Manzo $M$, Moscarella $E$ et al. Frequency of dermoscopic nevus subtypes by age and body site: a crosssectional study. Arch Dermatol. 2011;147:663-70.

14. Pope DJ, Sorahan T, Marsden JR, Ball PM, Grimley RP, Peck IM. Benign pigmented nevi in children. Prevalence and associated factors: The West Midlands, United Kingdom Mole Study. Arch Dermatol. 1992;128:1201-6.

15. Schafer T, Merkl J, Klemm E, Wichmann HE, Ring J, the KORA study group. The epidemiology of nevi and signs of skin aging in the adult general population: results of the KORA-Survey 2000. J Invest Dermatol. 2006;126:1490-6.

16. Arisanty R, Tanurahardja B. Profil keganasan primer kulit tersering di Departemen Patologi Anatomik RS Cipto Mangunkusumo tahun 2005-2009. Majalah Patologi Indonesia. 2011;20:14-20. Indonesian.

17. MacKie RM, Hauschild A, Eggermont AMM. Epidemiology of invasive cutaneous melanoma. Ann Oncol. 2009;20(Suppl 6):vi1-vi7.

18. Rokuhara S, Saida T, Oguchi M, Matsumoto K, Murase S, Oguchi S. Number of acquired melanocytic nevi in patients with melanoma and control subjects in Japan: nevus count is a significant risk factor for nonacral melanoma but not for acral melanoma. J Am Acad Dermatol. 2004;50:695-700. 
19. Jung $H J$, Kweon SS, Lee JB, Lee SC, Yun SJ. A clinicopathologic analysis of 177 acral melanomas in Koreans: relevance of spreading pattern and physical stress. JAMA Dermatol. 2013;149:1281-8.

20. Park SJ, Oh CM, Kim BW, Woo SJ, Cho H, Park $\mathrm{KH}$. Nationwide incidence of ocular melanoma in South Korea by using the national cancer registry database (1999-2011). Invest Ophthalmol Vis Sci. 2015;56:4719-24.

21. Wulandari N. Karakteristik gambaran klinis dan dermoskopi nevus melanositik didapat pada tipe kulit orang Indonesia. Jakarta: Universitas Indonesia; 2013. Indonesian.
22. Moreno S, Soria X, Martinez M, Marti RM, Casanova JM. Epidemiology of melanocytic naevi in children from Lleida, Catalonia, Spain: protective role of sunscreen in the development of acquired moles. Acta Derm Venereol. 2016;96:479-84.

23. Chang $Y$, Newton-Bishop JA, Bishop DT, Armstrong BK, Bataille V, Bergman W, et al. A pooled analysis of melanocytic naevus phenotype and the risk of cutaneous melanoma at different latitudes. Int $\mathrm{J}$ Cancer. 2009;124:420-8.

24. Sellheyer K, Bergfeld WF. A retrospective biopsy study of the clinical diagnostic accuracy of common skin diseases by different specialties compared with dermatology. J Am Acad Dermatol. 2005;52:823-30. 